\title{
Postsurgical dysphagia: evaluation and rehabilitation
}

\author{
S Biondi, M Zappalà, G Biondi \\ From de Senectute: Age and Health Forum \\ Catanzaro, Italy. 5-7 December 2009
}

Surgical resection of a malignant tumor in the head and neck regions quite often alters the complex act of swallowing. The goal of dysphagia rehabilitation is to return the patient's swallowing to as near normal as possible. Although surgical procedures in the oral cavity, tongue, pharynx can affect preparation, control and transport of the bolus, functional disorders following laryngeal surgery are most common and severe. The larynx serves two critical functions during swallowing. First, it elevates anteriorly moving itself from the path of the bolus and contributing to the opening of the cricopharyngeal sphincter. Second, it protects the airways from inhaling acting as a three level valve - the epiglottis, false vocal folds, and true vocal folds. Any surgical intervention affecting this closure will likely results in aspiration during the swallow. Patients undergoing total laryngectomy have few swallowing problems due to the separation of the airways from the esophagus. On the contrary both partial and reconstructive procedures can significantly affect both the respiratory and the alimentary function. Supraglottic laryngectomy can interfere with laryngeal elevation and sometimes with vocal fold adduction especially when the surgical procedure includes portions of the hyoid bone, base of tongue, aryepiglottic folds, or false vocal folds. Vertical laryngectomies reduce laryngeal closure. When the intervention is limited to one focal fold (cordectomy), the swallowing recovery is usually easily achieved. In frontolateral laringectomy the removal of tissues extends to the opposite vocal fold: in such cases swallowing recovery is still possible with a combination of increased effort and compensatory head posturing. In sub-total/reconstructive laryngectomies (Crico-Hyoido-Epiglotto-Pexy, CHEP and Crico-HyoidoPexy, CHP) the surgeon intends to create a neoglottis able to contracts during swallowing. In such cases

Dipartimento di Specialità Medico-Chirurgiche, Policlinico Università di Catania, via S. Sofia 78 - 95123, Catania, Italy critical factors in recovery of swallowing are considered the airway closure at the laryngeal entrance, the propulsive movement of the tongue base and its contact with the posterior pharyngeal wall.

Two pernicious, life-threatening complications can slowly compromise the patient's life aspiration, pneumonia and malnutrition.

Diagnostic procedures of swallowing disorders are mainly represented by radiographic contrast examination and by fiberoptics endoscopic evaluation.

Compensatory treatment strategies include postural changes, increasing sensory input, modifying volume, consistency and viscosity of foods.

Rehabilitative procedures are designed to improve a range of movements of oral or pharyngo-laryngeal structures and increase their sensory-motor integration and timing. Exercises and manoeuvres designed to achieve such goals are considered in detail.

Published: 19 May 2010

doi:10.1186/1471-2318-10-S1-L51

Cite this article as: Biondi et al.: Postsurgical dysphagia: evaluation and rehabilitation. BMC Geriatrics 2010 10(Suppl 1):L51.

Submit your next manuscript to BioMed Central and take full advantage of:

- Convenient online submission

- Thorough peer review

- No space constraints or color figure charges

- Immediate publication on acceptance

- Inclusion in PubMed, CAS, Scopus and Google Scholar

- Research which is freely available for redistribution

Submit your manuscript at www.biomedcentral.com/submit
Ciomed Central 